\title{
Strategic Agility on SME: A Case Study of Small Doll Industry in Bandung
}

\author{
$1^{\text {st }}$ Widjajani \\ Program Studi Teknik Industri \\ Fakultas Teknik \\ Universitas Langlangbuana \\ Indonesia \\ niawidjajani@gmail.com
}

\author{
$2^{\text {nd }} \mathrm{R}$ Nurjaman \\ Program Studi Teknik Industri \\ Fakultas Teknik \\ Universitas Langlangbuana \\ Indonesia
}

\author{
$3^{\text {rd }}$ E Dwipriyoko \\ Program Studi Informatika \\ Universitas Langlangbuana \\ Indonesia
}

\begin{abstract}
The rapidly changing business environment requires every company to be adaptive in order to survive. Likewise, it is experienced by small industrial companies in Indonesia. With limited capital, it is not easy for them to be agile in facing environmental changes that threaten business continuity. The purpose of this research is to study how the strategic agility of a small industry in dealing with a changing environment. This research is a case study in a small doll industrial company in Bandung, West Java Province of Indonesia, which was carried out in 2007, 2011 and 2019. The method used is a qualitative method. The results of the study illustrate the change in business model that reflects the strategic agility of this small industrial company to be able to survive in a changing environment that threatens the survival of their business.
\end{abstract}

Keywords-Strategic, SME, Industry, Bandung

\section{INTRODUCTION}

Small and Medium Enterprises have an important role in improving people's welfare, therefore it is desirable that SME in a country can advance and develop, as well as in Indonesia. The condition of the industrial environment in Indonesia is uncertain, especially for Small Industries, causing companies have to struggle in order to survive. Disruption often threatens business continuity. Therefore, companies must be able to make strategic commitments so that the company does not go out of business [1].

This research is a case study in a doll manufacturing SME in Bandung, West Java Province. Observations were carried out longitudinally from 2007 to 2019 in the doll cluster. The selected company was the most successful company in 2007 in the cluster, and then monitored what was experienced and the strategies undertaken to deal with the problems encountered until 2019.

Companies that are in an uncertain environment, and experiencing turbulence, must be agile if they want to survive and not go out of business. [1] argue that an agile organization is one that can adapt to a disruptive environment. Companies that have strategic agility can make strong strategic commitments, but besides that they also have awareness, flexibility and are able to adapt these commitments if needed by the business environment [2].

In dealing with changes and strategic disruption, often companies have to change their business models [3]. Business Model (BM) is a depiction of how companies can create value and distribute it. Companies that have strategic agility will be able to survive facing environmental disruption that can threaten the survival of their business, namely by updating the business model. This paper aims to describe how a small doll industry that experienced turbulence from its environment requires to be agile so that it could survive.

SME is a business that is characterized by the management of one person, namely the owner manager. Strategic decisions are determined by the owner manager, so that entrepreneurial competence possessed by the owner manager largely determines business continuity. This research focuses on how the strategic decisions that have been taken by managers of small doll industry owners during the course of their business since it was founded (1993) until 2019 [3].

This paper is structures as follows: Section 2 reviews the relevant literature, Section 3 explains the methodology, Section 4 presents analysis and discussions, Section 5 draws conclusions.

\section{LITERATURE REVIEW}

A. Strategic Agility

According to [2], strategic agility is the ability of organizations to be able to create fast, decisive and effective actions to be able to anticipate and utilize change. Furthermore, [3] argue that strategic agility consists of 3 meta-capabilities, namely: strategic sensitivity, leadership unity and resource fluidity. Strategic sensitivity refers to the sharpness of perception and the intensity of awareness and attention that leads to strategic development. Leadership Unity is the ability of leaders to make quick and courageous decisions. While resource fluidity is an internal capability that is able to reconfigure capabilities and move and re-use resources quickly. 
Companies need these three meta-capabilities to be able to form strategic agility, if only one or two metacapabilities are not sufficient [2]. To be able to plan the development of a company needs the ability to predict the future and produce the right and strategic decisions. The ability to make good decisions will not be useful if it cannot be implemented. Implementation of decisions requires resources that need to be re-engineered to produce the best output.

Strategic agility is needed since the business environment changes rapidly and is difficult to predict. Companies that used to maintain a long-term position of excellence now need agility to face disruption and discontinuity. The existence of strategic disruption and discontinuity often requires companies to change their business models immediately, while for the sake of stability and efficiency, companies must implement changes slowly. The success of business model renewal and transformation is the main output of strategic agility ([3]; [4]). For this reason, [3] provides a leadership agenda to accelerate the renewal of business models in implementing inherent strategic agility.

The leadership agenda is a list of leadership priorities and actions related to each meta capability that can accelerate the renewal and transformation of the business model [3]. [3] proposed five leadership agendas for each meta capability. For the strategic sensitivity dimension, the leadership actions are anticipating, experimenting, distancing, abstracting and re-framing. Leadership actions for meta capability leadership unity are to dialogue, revealing, integrating, aligning and caring. The meta capability of resource fluidity has proposed leadership actions namely decoupling, modulating, dissociating, switching and grafting.

\section{B. Business Model (BM)}

Business Model (BM) is a description of cognitive structure how to determine company boundaries, how to create value and how to organize internal structures and their management [3]. Of all these models, BM Canvas [5] which is non-technical in nature so that it can be applied more broadly and most easily applied [6]. BM Canvas consists of 9 components [5], namely infrastructure (backend) consisting of key partners, key activities and key resources; the product described by the value proposition; the consumer part consisting of customer relationships, channels and customer segments (figure 1).

Some researchers mention that BM has a close relationship with strategy ([7]; [8]; [9]). Some researchers provide steps to implement BM ([10]; [11]; [9]), but basically all can be said to be a combination of the steps of determining values and strategies to realize them at various levels for example, strategic planning, strategic positioning, strategic learning, etc.

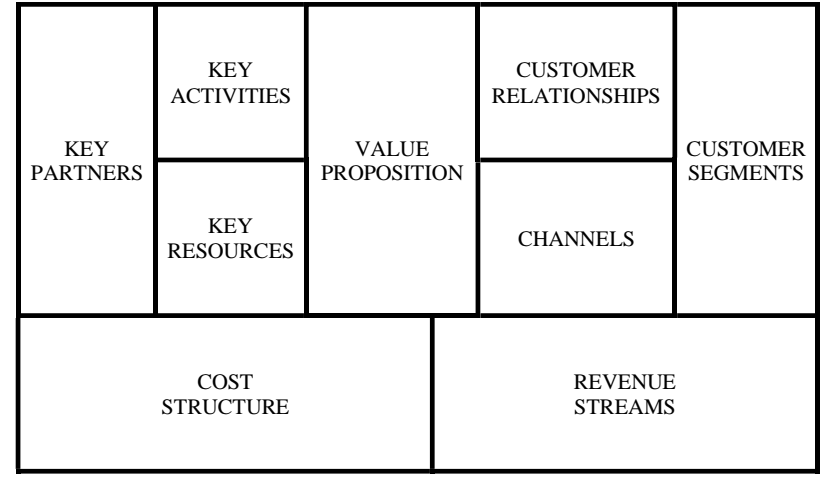

Fig. 1. The Business Model Canvas [5]

\section{Strategic Agility and BM renewal in $S M E$}

Several researchers have examined the relationship between strategic agility and BM renewal in SME. One of them is [4] who explores how the capabilities that underlie strategic agility can be appropriate for the context of SME in the service sector. The results of their research found that leadership unity and resource fluidity are suitable for SME. While strategic sensitivity is also found, but it really depends on the owner manager as an individual. Another meta capability was found, namely resourcefulness, which was broadly defined as the ability to overcome limitations, especially in the human resource and financial sector.

\section{METHODOLOGY}

This study uses a single case study with the methodology adopted is qualitative, exploratory with an inductive approach. Longitudinal data were taken using semi-structured interviews with informants of the owners of small doll industry owners.

Company background

The "M" Doll Company was founded by Mr. Y in 1993 and is located in a small industrial cluster in the province of West Java. At that time there were about 35 doll companies there, with similar business model characteristics. All companies have a mass production strategy, selling cheaply for the lower middle market segment. The raw material used is waste cloth from large companies and the production process is done manually with hand stitching without using a pattern as a template, so that the product is not standardized and the production capacity is very dependent on the number of employees working. At the beginning of running a business, Mr. Y implemented the same production strategy as other companies because at that time the level of demand for these dolls was high so there was less business risk. In 1996, Mr. Y felt that if he continued to implement the same strategy, then his business would not be able to develop, due to limited capital making it impossible for him to have a large workforce, therefore he then changed his business model drastically. As a result of the change in business model, when in 2007 a study was conducted on the cluster, Mr. Y's small doll industry was the company that had the most competitive advantage in the cluster [12].

In 2011, the company experienced turbulence caused by the implementation of the ASEAN Free Trade Area (AFTA) and a reduction in import duties so that many products at lower prices from abroad circulated in the 
market. While the cost of production increases because the price of fabric raw materials increases, the minimum wage rises and also the obligation to register the Indonesian National Standards for each type of product that also requires costs. In that year, Mr. $\mathrm{Y}$ then renewed his business model, but only in the market aspect. In 2019 a study was conducted again on the company and found the fact that the company had been able to rise again and become a company that could survive in the cluster, while many other companies had closed. Table 1. describes the history of business model renewals with the leadership agenda undertaken to carry out business model updates.

TABLE I. BUSINESS MODEL RENEWAL AND RELATED LEADERSHIP AGENDAS

\begin{tabular}{|c|c|c|c|c|c|}
\hline Year & $\begin{array}{l}\text { Driver for } \\
\text { BM renewal }\end{array}$ & $\begin{array}{c}\text { Meta } \\
\text { capabilities } \\
\text { for Strategic } \\
\text { Agility } \\
\end{array}$ & $\begin{array}{c}\text { Leadership } \\
\text { action agenda }\end{array}$ & Description & BM components \\
\hline 1993 & & & & & $\begin{array}{l}\text { Value Proposition: cheap dolls } \\
\text { Key Activities: labor intensive, mass } \\
\text { production, sewing by hand } \\
\text { Key Resources: number of workers } \\
\text { Key Partners: Big doll company that } \\
\text { throw the remaining fabrics of doll raw } \\
\text { materials } \\
\text { Customer Relationship: Meet as much } \\
\text { as consumer demand } \\
\text { Channels: Re-seller } \\
\text { Customer segments: middle to lower } \\
\text { segments } \\
\text { Cost structure: labor cost, economies } \\
\text { of scale } \\
\text { Revenue steams: number of products }\end{array}$ \\
\hline \multirow[t]{6}{*}{1996} & $\begin{array}{l}\text { Competitive } \\
\text { intensity }\end{array}$ & $\begin{array}{l}\text { Strategic } \\
\text { sensitivity }\end{array}$ & $\begin{array}{l}\text { Anticipating, } \\
\text { abstracting }\end{array}$ & $\begin{array}{l}\text { Create doll products } \\
\text { for the upper middle } \\
\text { segment consumer }\end{array}$ & \multirow{6}{*}{$\begin{array}{l}\text { Value Proposition: Quality Dolls } \\
\text { Key Activities: pattern-based } \\
\text { production, sewing by machine, } \\
\text { quality control } \\
\text { Key Resources: pattern maker, skilled } \\
\text { work forces, subcontractor (reserve } \\
\text { capacity) } \\
\text { Key Partners: fabric factory (supplier) } \\
\text { Customer Relationship: co-design, co- } \\
\text { creation } \\
\text { Channels: department stores (make-to- } \\
\text { stock), exporter companies (make-to- } \\
\text { order) } \\
\text { Customer segments: upper middle } \\
\text { segment } \\
\text { Cost structures: value driven } \\
\text { Revenue streams: quality of products }\end{array}$} \\
\hline & & $\begin{array}{l}\text { Strategic } \\
\text { sensitivity }\end{array}$ & $\begin{array}{l}\text { Abstracting, } \\
\text { experimenting, } \\
\text { re-framing }\end{array}$ & $\begin{array}{l}\text { Making puppet } \\
\text { patterns from two- } \\
\text { dimensional images } \\
\text { (photographs), and } \\
\text { producing with a } \\
\text { modular concept }\end{array}$ & \\
\hline & & $\begin{array}{l}\text { Strategic } \\
\text { sensitivity }\end{array}$ & $\begin{array}{l}\text { Abstracting, re- } \\
\text { framing }\end{array}$ & $\begin{array}{l}\text { Replace raw material } \\
\text { suppliers into fabric } \\
\text { factories that can } \\
\text { provide a lot of good } \\
\text { quality raw materials }\end{array}$ & \\
\hline & & $\begin{array}{l}\text { Leadership } \\
\text { unity }\end{array}$ & $\begin{array}{l}\text { Revealing, } \\
\text { caring }\end{array}$ & $\begin{array}{l}\text { Maintaining skilled } \\
\text { and well-trained } \\
\text { permanent employees }\end{array}$ & \\
\hline & & $\begin{array}{l}\text { Resources } \\
\text { fluidity }\end{array}$ & $\begin{array}{l}\text { Decoupling, } \\
\text { modulating }\end{array}$ & $\begin{array}{l}\text { Changing production } \\
\text { organizations to be } \\
\text { modular so that they } \\
\text { are more flexible in } \\
\text { dealing with product } \\
\text { variations }\end{array}$ & \\
\hline & & $\begin{array}{l}\text { Resource } \\
\text { fluidity, } \\
\text { leadership } \\
\text { unity }\end{array}$ & $\begin{array}{l}\text { Decoupling, } \\
\text { grafting, } \\
\text { integrating, } \\
\text { aligning }\end{array}$ & $\begin{array}{l}\text { Fostering and } \\
\text { training } \\
\text { subcontractors on the } \\
\text { concept of production } \\
\text { quality so that it can } \\
\text { become a reserve } \\
\text { capacity }\end{array}$ & \\
\hline 2011 & $\begin{array}{l}\text { Regulatory } \\
\text { turbulence, } \\
\text { competitive } \\
\text { intensity }\end{array}$ & $\begin{array}{l}\text { Strategic } \\
\text { sensitivity }\end{array}$ & $\begin{array}{l}\text { Anticipating, } \\
\text { abstracting, re- } \\
\text { framing }\end{array}$ & $\begin{array}{l}\text { Look for new } \\
\text { markets by accepting } \\
\text { doll orders for } \\
\text { souvenirs from } \\
\text { companies or event } \\
\text { organizers }\end{array}$ & $\begin{array}{l}\text { Value Proposition: Quality Dolls } \\
\text { Key Activities: pattern-based } \\
\text { production, sewing by machine, } \\
\text { quality control } \\
\text { Key Resources: pattern maker, skilled } \\
\text { work forces, subcontractor (reserve } \\
\text { capacity) } \\
\text { Key Partners: fabric factory } \\
\text { Customer Relationship: co-design, co- } \\
\text { creation } \\
\text { Channels: companies, event organizers } \\
\text { (make-to-order) } \\
\text { Customer segments: upper middle } \\
\text { segment } \\
\text { Cost structures: value driven } \\
\text { Revenue streams: quality of products }\end{array}$ \\
\hline
\end{tabular}




\section{ANALYSIS AND DISCUSSION}

The research findings show that strategic agility in SME is determined by the capability of the owner manager who carries out the inherent leadership agenda in dealing with extremely dynamic environmental conditions. All three meta-capabilities proposed by Doz and Kosonen [3] are found in the small doll industry in West Java Province which has strategic agility. In the SME context, the three meta capabilities are the capabilities that every owner manager must have to build strategic agility.

To obtain strategic agility, the owner manager must carry out a comprehensive BM renewal on all BM components so that all can be decided to support each other effectively and efficiently.

\section{CONCLUSIONS}

The key findings are summarized as follows. First, three proposed meta-capabilities [2][3], namely strategic sensitivity, leadership unity and resource fluidity were found in the SME studied. These meta-capabilities are personal competencies possessed by the owner manager. This case illustrates that owner managers who have these meta-capabilities are a prerequisite for SME strategic agility.

The second finding is, strategic agility will require renewal of BM, and good BM will result in competitive advantage. The combination of competitive advantage and strategic agility will be able to lead to sustainable competitive advantage. The second finding is, strategic agility will require renewal of BM, and good BM will result in competitive advantage. The combination of competitive advantage and strategic agility will be able to lead to sustainable competitive advantage.

The limitation of this study is in the use of a single case study from manufacturing sector only. Findings from other case studies can be used to perfect conclusions about the relationship between strategic agility, renewal BM and sustainable competitive advantage. In addition, further research can be directed at the competencies that must be possessed by small business owner managers in order to enrich the knowledge of entrepreneurship.

\section{REFERENCES}

[1] Weber Y and Tarba S Y Strategic Agility: A State of the Art: Introduction to the Special Section on Strategic Agility California Management Review 56.3. 2014

[2] Doz, Y L and Kosonen M The Dynamics of Strategic Agility: Nokia's Rollercoaster Experience California Management Review 50.3. 2008

[3] Doz Y L and Kosonen M Embedding Strategic Agility: A Leadership Agenda for Accelerating Business Model Renewal Long Range Planning 43.2-3 370-382. 2010

[4] Arbussa A, Bikfalvi A and Marquès P Strategic agility-driven business model renewal: the case of an SME Management Decision Vol. 55 Iss 2271 - 2932017

[5] Osterwalder A and Pigneur Y Business Model Generation: A Handbook for Visionaries, Game changers and Challengers John Wiley \& Sons Hoboken NJ 2010

[6] Heikkilä M, Bowman H, Heikkilä J From strategic goals to business model innovation paths: an exploratory study $J$. of Small Business and Enterprise Development 25:1 107-128. 2018

[7] Klang D, Wallnofer M, and Hacklin F The Anatomy of the Business Model: A syntactical Review and Research Agenda Driud Summer Conference 2010
[8] Casadesus-Masanell R and Ricart J E From Strategy to Business Models and onto Tactics Long Range Planning 43.2-3, pp. 1952152010

[9] Teece D J Business Models, business strategies and innovation Long Range Planning 43(2-3) 172-194 2010

[10] Berends H, Smits A, Reymen I and Podoynitsyna K Learning while (re)configuring: business model innovation processes in established firms Strategic Organization Vol. 14 No. 3 181-219. 2016

[11] Frankenberger K, Weiblen T, Csik M and Gassmann O The 4Iframework of business model innovation: a structured view on process phases and challenges Int'l J. of Product Development, Vol. 18 Nos 3-4, pp. 249-273 2013

[12] Widjajani Entrepreneurship: Perilaku Strategis Industri Kecil untuk Membangun Keunggulan Kompetitif Rekayasa Sains Bandung 2014

[13] Dwipriyoko,E., Bon,ATB , \& Sukono, F. Enterprise Architecture Planning as New Generation Cooperatives Research Methods. In Journal of Physics: Conference Series (Vol. 1179, No. 1, p. 012094). IOP Publishing. 2019

[14] Dwipriyoko,E., Widjayani . Partial Business Process Reengineering in New Generation Cooperatives Enterprise Architecture Implementation. In Journal of Physics: Conference Series (Vol. 1477, ). IOP Publishing. 2020

[15] Widjajani, Nurjaman, R. The Framework of Strategic Agility in Small and Medium Enterprise. In Journal of Physics: Conference Series (Vol. 1477, ). IOP Publishing. 2020

[16] Gumilar,AC., Afrian,NFS., Pramiarsih,EE., Widjadjani, The Effect of Mathematics Learning With Improve Method to the Mathematical Representation Ability of Junior High School Students. In Journal of Physics: Conference Series (Vol. 1477, ). IOP Publishing. 2020

[17] Sutarman,E., Widjajani, Dwipriyoko,E. Effect of Additive Chemicals on Soil Characteristics. In Journal of Physics: Conference Series (Vol. 1477, ). IOP Publishing. 2020

[18] Ridha,MR., Pramiarsih,EE., Widjajani, The Use Of Geogebra Software In Learning Geometry Transformation To Improve Students' Mathematical Understanding Ability In Journal of Physics: Conference Series (Vol. 1477, ). IOP Publishing. 2020 